\title{
SPOTLIGHT ON-THE NATIONAL ASSOCIATION OF LEARNING LABORATORY DIRECTORS
}

The National Association of Learning Laboratory Directors (NALLD) was originally established as the National Association of Language Laboratory Directors at the 1965 annual convention of the Asscciation for Educational Communications and Technology (AECT). The Association was founded in response to the need for a nonprofit organization of media professionals active in the field of language acquisition. The original stated purpose of the Association has always remained the promotion of more effective use and better understanding of mediated instruction in all areas and levels of education. Due to diversification and growing acceptance of the use of electronics laboratories for teaching subjects other than foreign languages, the Association modified its title from Language to Learning laboratories in the mid-1970's. Today, this diversified, professional organization counts among its members, teachers, media specialists and administrators in practically all areas of education throughout the world.

As an independent organization, NALLD owes its continued existence to the enthusiasm and motivation of individual members who have volunteered to serve the Association and thereby the profession wherever needed. The NALLD Executive Board of Directors, which shapes the policies and future of the Association, is composed of the President, VicePresident/President-Elect, Executive Secretary, Treasurer, Recording Secre-tary, Director of the Publications Center and Editor of The NALLD Journal: Technology and Mediated Instruction. An annual business meeting is usually held concurrenly with a major educational conference. In this meeting, the membership discusses and adopts resolutions concerning problems of general interest to the profession. Such resolutions are intended to improve and standardize techniques used in learning lab-media resource centers. The Association's major income is derived from membership dues and from commercial advertisements in the Journal. The Association's major income is derived from membership dues and from commercial advertisements in the Journal. The Association's major expense is publishing the Journal. 
The NALLD Journal: Technology and Mediated Instruction first appeared in February 1966. Since then, it has evolved from an occasional mimeographed newsletter into a journal distributed worldwide from its current headquarters at the University of Louisville in Louisville, Kentucky. Contributors to the Journal have ranged from parttime lab directors to world scholars. The Editor welcomes and actively seeks articles on mediated instruction, hardware/software reviews and notes of general interest. The mailing address of the Journal is:

NALLD Journal: Technology and Mediated Instruction

Arts \& Science Learning Lab

Bingham Humanities Building 16

University of Louisville

Louisville, Kentucky 40292

NALLD also maintains a Publications Center at Ohio University in Athens, Ohio. The NALLD Publications Center exists in order to catalogue and distribute free of charge to NALLD members reprints of official Association business, sample copies of forms used in laboratories, as well as copies of technical and teaching material from operating laboratories. All NALLD members are encouraged to forward items for possible inclusion in the NALLD Publications Center collection to:

Mr. Charles Richardson, Director

NALLD Publications Center

Ohio University, Ellis Hall

Athens, $\mathrm{OH} 45701$.

The NALLD Publications Center also maintains a central registry of qualified members who act as consultants to representatives of education and industry requiring advice on media hardware and/or software.

Finally, the organization and all individual board members are committed to establishing and maintaining active lines of communication and close ties not only with and between NALLDs own worldwide membership, but also with other national and international media and academic organizations.

The co-sponsorship of the first international conference on Foreign Language Education and Technology by the National Association of Learning Laboratory Directors and the Language Laboratory Association of Japan represents a concrete effort by NALLD to achieve these goals. Membership in the organization is open to anyone interested in mediated instruction. Won't you join us? For membership information contact:

Office of Academic Affairs

Gardiner Hall 240

University of Louisville

Louisville, Kentucky 40292 